\title{
PENGARUH PENERAPAN PENDIDIKAN SEKS (MEDIA ULAR TANGGA) TERHADAP KEMAMPUAN PENCEGAHAN KEKERASAN SEKSUAL PADA ANAK JALANAN DI KAMPUNG SAVANA KOTA MAKASSAR
}

\author{
Sitti Nurbaya ${ }^{1)}$, Merlis Simon ${ }^{2)}$, \\ ${ }^{1}$ Program Studi S1 Keperawatan, STIKES Nani Hasanuddin Makassar \\ Email: nurbaya.baya@gmail.com \\ ${ }^{2}$ Program Studi Ners, STIKES Nani Hasanuddin Makassar
}

\begin{abstract}
The Indonesian Child Protection Commission confirmed the sexual violence against children was still a major problem. In 2015 the category of children dealing with the law ranked first, namely cases of sexual violence against children (Rape, molestation, sodomy / pedophilia) as many as $18 \%$ or 193 victims of the second place violence as victims of physical violence as much as $17 \%$ or 182 cases and the third order as children perpetrators of sexual violence $12.9 \%$ or 138 cases. The Makassar City Women's Empowerment and Child Protection Agency noted that there were at least 1,160 cases of child abuse in Makassar City in 2017. This was due to the lack of efforts of children, adolescents, parents and teachers to early prevention. The purpose of this study was to determine the effect of the implementation of sex education (sanake and ladder game media) on the ability to prevent sexual violence on street children in Savana, Makassar City. The type of this research used a Quasy Experimental research design with a Pre-post test design approach. This research was conducted in Savana Village Bangkala Village, Manggala. District, Makassar on March 27-30 August 2019. The population of the study was 45 children, based on the population, then taken a sample of 40 respondents. Statistical test results showed there was an influence of sex education (snake ladder media) on the prevention ability of sexual violence in children with a value ( $p=0,000$, smaller than $a=0.05)$. So, it can be concluded that there was a significant effect on the application of sex education (snake ladder media) to prevention of sexual violence against street children in Savana village, Makassar City.
\end{abstract}

Keywords : sexual violence, Child, Education 


\begin{abstract}
Abstrak
Komisi Perlindungan Anak Indonesia (KPAI) menegaskan kekerasan seksual pada anak masih menjadi masalah utama. Tahun 2015 ketegori anak berhadapan dengan hukum menepati urutan pertama yaitu kasus kekerasan seksual pada anak (Pemerkosaan, pencabulan, sodomi/pedofilia) sebanyak 18\% atau 193 korban kekerasan urutan kedua anak sebagai korban kekerasan fisik sebanyak 17\% atau 182 kasus dan urutan ketiga anak sebagai pelaku kekerasan seksual 12,9\% atau 138 kasus Dinas Pemberdayaan Perempuan dan Perlindungan Anak Kota Makassar mencatat sedikitnya ada 1.160 kasus kekerasan anak di Kota Makassar tahun 2017. Hal tersebut disebabkan minimnya upaya anak, remaja, orang tua dan guru terhadap pencegahan sejak dini. Tujuan penelitian ini untuk mengetahui pengaruh penerapan pendidikan seks (media ular tangga) terhadap kemampuan pencegahan kekerasan seksual pada anak jalanan di kampung Savana Kota Makassar. Jenis penelitian ini menggunakan rancangan penelitian Quasy Experimen dengan pendekatan Pre-post test design. Penelitian ini dilaksanakan di Kampung Savana Kelurahan Bangkala Kecamatan Manggala Makassar pada 27 Maret- 30 Agustus tahun 2019. Populasi dalam penelitian ini sebanyak 45 anak berdasarkan populasinya maka diambil sampel sebanyak 40 responden. Pengumpulan data menggunakan kuesioner dengan uji statistik Mcnemar. Hasil uji statistik terdapat pengaruh pendidikan seks (media ular tangga) terhadap pencegahan kekerasan seksual pada anak dengan nilai ( $p=0,000$, lebih kecil dari $\alpha=0,05)$ jadi dapat disimpulkan terdapat pengaruh penerapan pendidikan seks (media ular tangga) terhadap pencegahan kekerasan seksual pada jalanan di kampung Savana Kota Makassar.
\end{abstract}

Kata Kunci: Pendidikan Seks, Ular Tangga, Kekerasan Seksual, Anak Jalanan,. 


\section{PENDAHULUAN}

Kekerasan pada anak sebelum usia 18 tahun didapatkan data anak usia 18 sampai 24 tahun usia tersebut mereka telah mengalami korban kekerasan seksual selama masa kanak-kanak atau sebelum usia 18 tahun dimana 32\% terjadi pada anak perempuan dan $18 \%$ terjadi pada anak laki-laki. Pelaku paling umum tindak kekerasan seksual mereka adalah lakilaki dari pacar korban atau teman bermesraan mereka sebanyak $47 \%$, dan $43 \%$ pelaku dilakukan dari tetangga mereka. Selanjutnya tiga dari sepuluh perempuan $30 \%$ berumur 18-24 tahun melaporkan pernah mengalami tindak kekerasan seksual sebelum usia18 tahun seperti (seks bentuk fisik, paksaan, ditekan) sampai hasilnya menjadi hamil (UNICEFT, 2010).

Efek yang ditimbulkan akibat kekerasan baik pada anak kelompok usia 18-24 tahun yang mengalami kekerasan sebelum berusia 18 tahun diantaranya bagi anak perempuan berefek dalam bentuk fisik mabuk-mabukan (14\%), menyakiti dirinya sendiri $(6,06 \%)$, merokok $(5,69 \%)$. Dan efek secara emosional menyakiti sendiri dirinya (42,9\%), mencoba bunuh diri $(34,4 \%)$ terpikir bunuh diri, $(32,6 \%)$. Efek bagi anak laki-laki sefek secara fisik merokok (78\%) mabuk (33\%) efek emosional merokok (57,5\%) mabuk $(42,7 \%)$ (Kurniasari, 2013 ).

Di Indonesia data dari Komisi Perlindungan Anak Indonesiia (KPAI) dengan kategori anak berhadapan hukum (ABH) mengalami peningkatan tiap tahunnya pada tahun 2013 terdapat 1.413 kasus, tahun 2014 terdapat 1428, dan tahun 2015 meningkat menjadi 2.208 kasus (KPAI, 2016)

Tahun 2015 data Komisi Perlindungan Anak Indonesia terdapat berbagai kasus kekerasan pada anak, seperti anak berhadapan dengan hukum $(\mathrm{ABH})$. Urutan pertama kategori kekerasan seksual pada anak (Pemerkosaan, pencabulan, sodomi/pedofilia) sebanyak $18 \%$ atau 193 korban kekerasan, urutan kedua anak sebagai korban kekerasan fisik 17\% atau 182 kasus serta urutan ketiga anak sebagai pelaku tindak kekerasan seksual $12,9 \%$ atau 138 kasus (KPAI, 2016)
Dinas Pemberdayaan Perempuan dan Perlindungan Anak (PPPA) mencatat sedikitnya ada 1.160 kasus kekerasan anak di Kota Makassar selama tahun 2017. Hal itersbut disebabkan karena minimnya pengetahuan anak, remaja, orang tua dan guru terhadap eksploitasi anak lewat media online. Kepala Dinas PPPA Kota Makassar mengatakan selama tahun 2017 pihaknya mencatat ada sekitar 1.106 kasus yang ditangani Pemerintah Kota (Pemkot) Makassar. Dan 500 kasus diantaranya adalah kasus terhadap anak dan lainnya adalah kasus perempuan yang meliputi kasus fisik, psikis, dan seksual (PPA, 2016).

Lokasi Kampung Savana kota Makassar Merupakan tempat yang didominasi oleh komunitas pemulung dan anak jalanan seperti saat observasi awal dan dilakukan wawancara anak jalanan di kampung Savana masih memiliki pencegahan kekerasan seksual yang kurang diperolah hasil wawancara 10 anak mengatakan merasa terbiasa bergaul dan bersentuhan dengan anak wanita dengan anak laki-laki. Dirinya juga mengatakan merasa terbiasa dengan pulang malam. 10 anak jalanan mengatakan dirinya tidak merasa takut atau kawatir jika ada sesorang memberikannya sesuatu atau diiming-mingi barang yang pemberinya tidak mereka ketahui siapa. 10 anak jalanan. Dari hasil waancara tersebut sehingga peneliti ingin memberikan solusi dengan melakukan penelitian fokus pada tindakan pencegahan kekerasan seksual khususnya anak jalanan di Kampung Savana Kota Makassar.

Pendidikan seks dengan media ular tangga sangat efektif dengan kemampuan anak . hal ini dijelaskna hasil penelitian mengatakan bahwa bermain melalui ular tangga sangat efektif dalam tindakan preventif kekerasan seksual. Selain menggunakan komunikasi verbal hal tersebut terdapat komunikasi non verbal. Dengan melihat tanda serta gambar pada ular tangga anak diharapkan mampu melakukan proses komunikasi dengan tepat sehingga tercapai maksud komunikasi yang diharapkan dalam pencegahan kekerasan seksual (Astuti, 2017). 


\section{METODE}

Dalam penelitian ini menggunakan rancangan Quasy Experimen, pendekatan Pre-post test design. Bertempat di Kampung Savana Kelurahan Bangkala Kecamatan Manggala Kota Makassar dan dilaksanakan pada tanggal 27 Maret - 30 Agustus tahun 2019 dengan populasi semua anak jalanan berusia 6-14 tahun di Kampung Savana sebanyak 45 anak. Berdasarkan populasinya maka dapat diambil sampel sebanyak 40 anak jalanan. Pengumpulan data menggunakan kuesioner dengan tujuan mengetahui upaya pencegahan kekerasan seksual anak sebelum dilakukan intervensi. Setelah dilakukan pengukuran awal, dilakukan kembali intervensi kepada anak jalanan dengan memberikan pendidikan seks (media ular tangga) selanjutnya diukur kemampuan pencegahan kekerasan seksual anak jalanan. Data primer didapat berdasarkan hasil pengisian responden atas kuesioner post test. Analisa data terbagi atas analisa univariat seperti data yang diperoleh dari masingmasing variabel dimasukkan dalam variabel frekuensi. Kemudian dilakukan analisis bivariat menggunakan uji ststistik $M C$ nemar dengan tingkat kemaknaan $\alpha=0,05$.

3. HASIL

1. Data Univariat

Tabel.1: Distribusi Frekuensi Responden Berdasarkan Jenis Kelamin Pada Anak Jalanan di Kampung Savana Kota Makassar

\begin{tabular}{|c|c|c|}
\hline Jenis Kelamin & n & \% \\
\hline Laki-Laki & 23 & 57.5 \\
\hline Perempuan & 17 & 42.5 \\
\hline Jumlah & 40 & 100 \\
\hline
\end{tabular}

Tabel.1 jenis kelamin responden dimana jenis kelamin terbanyak yaitu jenis kelamin laki-laki sebanyak 23 responden $(57,5 \%)$.

Tabel .2: Responden Berdasarkan Umur Pada Anak Jalanan di Kampung Savana Kota Makassar

\begin{tabular}{|c|c|c|}
\hline Umur & $\mathbf{n}$ & $\mathbf{\%}$ \\
\hline 5 Tahun & 5 & 12.5 \\
\hline 6Tahun & 4 & 10.0 \\
\hline 7Tahun & 5 & 12.5 \\
\hline 8Tahun & 6 & 15.0 \\
\hline
\end{tabular}

\begin{tabular}{|c|c|c|}
\hline 9 Tahun & 9 & 22.5 \\
\hline 10 Tahun & 6 & 15.0 \\
\hline 11 Tahun & 5 & 12.5 \\
\hline Jumlah & 40 & 100 \\
\hline
\end{tabular}

Tabel. 2 berdasarkan umur dimana umur terbanyak yaitu umur 9 tahun sebanyak 9 responden $(22,5 \%)$ dan umur terendah yaitu umur 5,7 dan 11 tahun sebanyak 5 responden (12.5).

a. Kelas Responden

Tabel .3 Responden berdasarkan kelas pada anak jalanan di kampung Savana Kota Makassar

\begin{tabular}{|c|c|c|}
\hline Kelas & n & \% \\
\hline Kelas 1 & 10 & 25.0 \\
\hline Kelas 2 & 5 & 12.5 \\
\hline Kelas 3 & 13 & 32.5 \\
\hline Kelas 4 & 1 & 2.5 \\
\hline Kelas 5 & 11 & 27.5 \\
\hline Jumlah & 40 & 100 \\
\hline
\end{tabular}

Tabel .3 menunjukkan data responden berdasarkan kelas dimana kelas terbanyak yaitu kelas 3 sebanyak 13 responden $(32,5 \%)$ dan kelas terendah yaitu kelas 4 sebanyak 1 responden $(2,5 \%)$.

b. Tinggal Bersama Responden

Tabel .4 Responden berdasarkan tinggal bersama pada anak jalanan di kampung Savana Kota Makassar

\begin{tabular}{|c|c|c|}
\hline $\begin{array}{c}\text { Tinggal Bersama } \\
\text { Responden }\end{array}$ & n & \% \\
\hline Orang Tua & 28 & 70.0 \\
\hline Keluarga/Nenek & 12 & 30.0 \\
\hline Jumlah & 40 & 100.0 \\
\hline
\end{tabular}

Tabel. 4 menunjukkan bahwa responden berdasarkan tinggal bersama terbanyak tinggal bersama orang tua yaitu 28responden $(70 \%)$.

\section{c. Jumlah Saudara}

Tabel .5 Distribusi Frekuensi Responden berdasarkan jumlah bersaudara pada anak pemulung di kampung Savana Kota Makassar

\begin{tabular}{|c|c|c|}
\hline Jumlah Saudara & $\mathbf{n}$ & \% \\
\hline 1 & 2 & 5.0 \\
\hline 2 & 6 & 15.0 \\
\hline 3 & 10 & 25.0 \\
\hline
\end{tabular}




\begin{tabular}{|c|c|c|}
\hline 4 & 8 & 20.0 \\
\hline 5 & 5 & 12.5 \\
\hline 6 & 8 & 20.0 \\
\hline 8 & 1 & 2.5 \\
\hline Jumlah & 40 & 100.0 \\
\hline
\end{tabular}

Tabel .5 Responden berdasarkan jumlah saudara terbanyak yaitu kelas 4 dan 6 bersaudara sebanyak 8 responden $(20,0 \%)$ dan jumlah saudara tedendah terendah yaitu 8 bersaudara sebanyak 1 responden $(2,5 \%)$.

\section{d. Pencegahan Anak Sebelum Pendidikan Seks}

Tabel .6 Responden berdasarkan pencegahan anak sebelum dilakukan pendidikan seks (media ular tangga) pada anak jalanan di Kampung Savana Kota Makassar

\begin{tabular}{|c|r|r|}
\hline $\begin{array}{c}\text { Pencegahan Anak } \\
\text { Sebelum dilakukan } \\
\text { Pendidikan Seks }\end{array}$ & n & \% \\
\hline Baik & 19 & 47.5 \\
\hline Kurang & 21 & 52.5 \\
\hline Jumlah & 40 & 100.0 \\
\hline
\end{tabular}

Tabel .6 Menunjukkan responden dengan pencegahan anak sebelum dilakukan pendidikan seks media ular tangga, pencegahan anak sebelum dilakukan pendidikan seks pencegahan baik sebanyak 19 responden $(47,5 \%)$ dan pencegahan anak kurang sebanyak 21 responden $(52,5 \%)$.

\section{e. Pencegahan Anak Sesudah dilakukan}

\section{Pendidikan Seks}

Tabel .7 Responden berdasarkan pencegahan anak sesudah dilakukan pendidikan seks (media ular tangga) di Kampung Savana Kota Makassar

\begin{tabular}{|c|r|r|}
\hline $\begin{array}{c}\text { Pencegahan Anak } \\
\text { Sesudah dilakukan } \\
\text { Pendidikan Seks }\end{array}$ & n & \multicolumn{1}{|c|}{} \\
\hline Baik & 32 & 80.0 \\
\hline Kurang & 8 & 20.0 \\
\hline Jumlah & 40 & 100.0 \\
\hline
\end{tabular}

Tabel .7 dipeoleh data responden dengan pencegahan anak sesudah dilakukan pendidikan seks media ular tangga dimana pencegahan anak baik sebanyak 32 responden $(80 \%)$ dan kurang sebanyak 8 responden $(20,0 \%)$.

\section{Bivariat}

a. Test Statistik pencegahan pre anak pencegahan post anak

Tabel. 8 Pengaruh pendidikan kesehatan terhadap pencegahan sebelum pendidikan kesehatan pada anak - pencegahan sesudah pendidikan kesehatan anak

\begin{tabular}{|l|r|}
\hline \multicolumn{2}{|c|}{ Test Statistics $^{\mathbf{a}}$} \\
\hline & $\begin{array}{l}\text { Pencegahan Sebelum \& } \\
\text { Pencegahan Sesudah }\end{array}$ \\
\hline $\mathrm{N}$ & 40 \\
\hline $\begin{array}{l}\text { Exact Sig. (2- } \\
\text { tailed) }\end{array}$ & 0.000 \\
\hline
\end{tabular}

Tabel.8 diperoleh data pengaruh pendidikan seks media ular tangga terhadap pencegahan sebelum dan sesudah dengan uji statistik MCNemar Test diperoleh nilai $\rho=0,000$ jika di dilihat nilai $\alpha=0,05$, maka $\rho<\alpha$. Hal ini menunjukkan bahwa terdapat pengaruh pendidikan seks (media ular tangga) terhadap pencegahan kekerasan seksual pada anak jalanan di kampung Savana Kota Makassar

\section{PEMBAhaSAN}

Berdasarkan hasil pengolahan dan analisis data didapatkan maka pembahasan ini diuraikan sesuai dengan tujuan penelitian dimana untuk mengetahui penerapan pendidikan seks (media ular tangga) terhadap kemampuan pencegahan kekerasan seksual pada anak jalanan di kampung Savana Kota Makassar

1. Pengaruh pendidikan seks (media ular tangga) terhadap kemampuan pencegahan kekerasan seksual pada anak jalanan di kampung Savana Kota Makassar

Didapatkan hasil antara variabel pengaruh pendidikan seks (media ular tangga) terhadap kemampuan pencegahan kekerasan seksual uji statistik Mcnemar dengan nilai $\rho=0,000$ jika dilihat dengan nilai $\alpha=0,05$, maka $\rho<\alpha$. Hal ini bebarti terdapat pengaruh pendidikan seks (media ular tangga) terhadap kemampuan 
pencegahan kekerasan seksual pada anak jalanan di kampung Savana Kota Makassar.

Pendidikan seks dengan media ular tangga berpengaruh dalam pencegahan perilaku seks. Hal ini, media ular tangga memudahkan siswa dalam memahami materi serta berdiskusi mengenai suatu kejadian tentang pencegahan perilaku seks, responden mengatakan merasa tertarik bermain ular tangga serta berdiskusi dengan teman lainnya sehingga dengan media permaina ular tangga memberikan pengaruh dalam hal ini meningkatkan pengetahuan anak dalam mencegah perilaku seks pra nikah (Safitri, 2017).

Penelitian ini searah dengan penelitian Zain (2017) diperoleh hasil sebelum dilakukan intervensi masih banyak siswa/i yang belum mengetahui mengenai Seksualitas, HIV/ AIDS dan Napza, namun setelah dilakukan simulasi permainan ular tangga terdapat perubahan simulasi permainan ular tangga merupakan salah satu kegiatan dari program Pusat Informasi Konseling Remaja yang dapat membantu membantu siswa siswi memperoleh informasi dan dapat membuat siswa siswi lebih termotivasi untuk memperoleh informasi yang lebih banyak mengenai kesehatan reproduksi siswa dalam hal inii seksualitas, HIV/ AIDS dan Napza.

Penelian lainpun sejalan yang telah dilakukan oleh Afandi (2015) hasil penelitian yaitu terjadi peningkatan hasil belajar siswa setelah dilakukan pembelajaran metode ular tangga. Menurutnya sebelum penerapan pembelajaran dengan media ular tangga diperoleh 55\% siswa dengan nilai diatas kriteria ketuntasan minimum, namun setelah penerapan pembelajaran ular tangga terdapat hasil $100 \%$ siswa mendapatkan nilai diatas minimum kriteria ketuntasannya.

Media ular tangga dalam penelitian ini telah dikemas dengan bentuk sederhana memasukkan pendidikan seks di dalamnya sehingga mudah dipahami oleh anak. Hal tersebut mendukung dan memberi motivasi pada anak dalam mengikuti kegiatan dengan serius sampai akhir permainan sehingga memberikan peningkatan preventif terhadap tindak kekerasan seksual anak dengan pendidikan seks permainan ular tangga.

Penelitian ini didukung dengan penelitian Mutmainnah (2014) dimana bentuk pencegahan kekerasan seksual kepada anak sangat diperlukan dengan pendekatan pendidikan seks diramu dengan bentuk penyampaian sederhana dan mudah dipahami anak contoh membekali anak dengan keterampilan sosial seperti asertif, bgaian ini terdapat pula di dalamnya program underwear rules. Tindakan asertif dimaksudkan yaitu kemampuan seorang anak diharapkan mampu mengungkapkan ketidak setujuannya atau penolakan secara tegas. Anak dilatih sehingga menjadi berani berkata "tidak" dengan tujuan untuk melindungi dirinya dengan berbagai kejahatan.

Berbagai langkah dalam menyampaikan pendidikan seksual pada anak diantaranya dengan aturan hal mana yang perlu ditutupi oleh pakaian dalam dan dapat dimulai mengajarkan anak dengan sederhana seperti memberitahu anak membersihkan alat genetalianya dengan benar baik setelah buang air kecil dan sesudah buang air besar sehingga diharapkan anak mampu secara sendiri dan meminimalisir meminta bantuan dengan orang lain. Selain itu ditekankan kepada anak tentang pentingnya menutupi alat genitalia anak. Pendidikan seks tersebut dengan demikian mampu mengajarkan anak untuk tidak sembarangan kepada mengijinkan orang lain membersihkan organ kelamin dirinnya, melihat atau memgang alat kelaminnya (Erni, 2013).

Dari hasi penelitian, peneliti berpendapat anak seharusnya mengetahui tubuh bagian tertentunya hanya boleh dilihat serta disentuh oleh orang lain. Meskipun kita ketahui orang lain biasa melakukannya dengan cara candaan memegang, namun selayakna anak tetap diajarkan untuk melawan serta melindungi dirinya dan menegaskan bahwa bagian tubuh tertentu tersebut tidak boleh sembarangan orang lain melihat atau memegangnya. Data yang diperoleh sebelum dilakukan pendidikan seks terdapat diantaranya anak justru menagggap biasa memperlihatkan bagian tubuh 
tertentunya dan terbiasa tidak memakai baju saat keluar kamar bahkan ia menjelaskan saat keluar dari rumah mereka kadang tidak memakai pakaian seperti baju. Setelah dilakukan pemberian seks media ular tangga siswa pada saat dilakukan post test oleh peneliti tentang pencegahan kekerasan seksual sebanyak $80 \%$ anak mampu menjawabnya dengan baik dalam artian upaya pencegahan mereka baik.

Hal tersebut terdapat pengaruh setelah dilakukan pendidikan seks dengan media ular tangga terbukti adanya peningkatan upaya mereka dalam dalam mencegah kekerasan seksual setelah dilakukan pendidikan seks permainan ular tangga. Hal ini karena pendidikan seks media ular tangga, anak merasa senang dalam menerima materi sambil bermain. Selain itu, anak merasa termotivasi dan merasa mudah dalam berdiskusi dengan fasilitator dan teman-temannya, anak pun merasa tidak malu menyampaikan apa yang ia alami dilingkungan rumah dan lingkungan sekitarnya dikarenakan suasana saat bermain ular tangga tidak terkesan serius sehingga anak tidak mengalami ketakutan saat menerima mataeri pencegahan kekerasan seksual pada anak.

Selain media ular tangga yang membuat anak termotivasi, yaitu materi yang disajikan dalam permainan tersbut cukup sederhana dengan memakai prinsip underwear rules sehingga anak cepat memahami aturan-aturan dalam pencegahan kekerasan seksual. Dalam hal ini memakai prinsip pakaian dalam atau underwear rules, dimana anak diberi pendidikan seks dan menekankan pada anak seperti bagian mana orang lain tidak diperbolehkan mencoba melihtat bagian yang tidak boleh dilihat atau menyentuh mereka, diharapkan pula anak mampu berperilaku atau merespon tidak suka atau berkata tidak jika terdapat orang ingin menyentuhnya dan bagaimana ia mampu menceritakan atau meminta bantuan kepada orang dewasa yang ia anggap percaya.

Dalam penelitian ini terdapat 8 anak memiliki pencegahan yang kurang setelah dilakukan pendidikan kesehatan. Hal ini dikarenakan saat dilakukannya pendidikan kesehatan masih terdapat responden yang perhatiannya kurang fokus kepada pemateri, dikarenakan satu grup dalam permainan ular tangga didapatkan tidak keseragaman dalam hal usia anak atau bercampur tingkatan usia anak sehingga mereka terkadang malu bercerita karena dilihat dan didengar dengan temannya yang lebih tua darinya.

\section{KESIMPULAN}

Terdapat pengaruh penerapan pendidikan seks (media ular tangga) terhadap kemampuan pencegahan kekerasan seksual pada anak jalanan di kampung Savana Kota Makassar

\section{UCAPAN TERIMA KASIH}

Penulis mengucapkan ucapan terima kasih yang sebesar-besarnya kepada:

1. Direktorat Jenderal Penguatan Riset dan Pengembangan Kementerian Riset, Teknologi, dan Perguruan Tinggi, atas kesempatannya dalam hibah penelitian dosen pemula

2. Ketua STIKES Nani Hasanuddin Makassar telah memberikan ijin dalam melaksanakan tugas penelitian

3. Kepala Unit Penelitian dan Pengabdian Masyarakat STIKES Nani Hasanuddin beserta staf kerja yang telah memberikan dukungan sehingga terlaksananya penelitian sesuai dengan jadwal yang telah direncanakan

4. Kepala LP2M UIN Alauddin Makassar yang telah bekerjasama dalam menerbitkan jurnal penelitian ini.

5. Kelurahan Bangkala Kecamatan Manggala Kota Makassar terima kasih telah mengijinkan kepada kami dalam melaksanakan penelitian

6. Responden yang telah bekerjasama dalam penelitian ini

7. Semua pihak telah membantu dalam penelitian hibah dosen pemula ini yang tak sempat kami sebutkan satu persatu kami ucapkan banyak terima kasih

\section{REFERENSI}


Afandi, R. 2015. Pengembangan Media Pembelajaran Permainan Ular Tangga Untuk Meningkatkan Motivasi Belajar Siswa dan Hasil Belajar IPS di Sekolah Dasar. JurnaI Inovasi Pembelajaran, 01.

Astuti, S. W. 2017. Pendidikan Seks pada Anak Taman Kanak-kanak Melalui Metode Permainan Ular Tangga "Aku Anak Berani" (Studi Deskripsi Komunikasi Interpersonal Anak dalam Bermain Ular Tangga "Aku Anak Berani”). Jurnal Promedia., Volume 3.

Erni .2013. Pendidikan Seks Pada Remaja. Jurnal Health Quality Vol. 3 No. $2 \mathrm{Mei}$ 2013,Hal. 69-140, 3 No 2.

KPAI. K. P. A. I. 2016. Anak Berhadapan Dengan Hukum [Online]. Jakarta. Available: http://www.kpai.go.id/\# 05 Agustus 2016].

Kurniasari.2013.Ringkasan Hasil Survey Kekerasan Terhadap Anak Indonesia Tahun 2013. Jakarta.Kementerian Sosial

Mutmainnah 2014. Membekali Anak Dengan Melindungi Diri.Vol III. Edisi I. Pp.443-451. Jurnal Pendidikan Anak, III Edisi I.

PPA, P. D. P. A. 2016. Kasus Kekerasan Anak di Kota Makassar Meningkat [Online]. Makassar. Available: http://news.rakyatku.com/read/4763/2016/05/ 15/kasus-kekerasan-anak-di-kota-makassarmeningkat [Accessed 06 Juli 2018].

Safitri, A. N. 2017. Pengaruh Edukasi Media Ular Tangga Terhadap Pengetahuan dan Sikap Remaja dalam Upaya Pencegahan Seks Pra Nikah di SMPN 1 Besuki Tulungagung, Surabaya, Universitas Airlangga.

UNICEFT 2010. Violence Against Children In Kenya Findings From a 2010 National Survey. Republic Of Kenya.

Zain, N. L. 2017. Pengaruh Simulasi Permainan Ular Tangga Genre Terhadap Pengetahuan dan Sikap Remaja tentang Triad KRR (Seksualitas, HIV dan AIDS, NAPZA)
Di SMPN 1 Tanjung Morawa Tahun 2016. JURNAL STIKNA Jurnal Sains, Teknologi, Farmasi \& Kesehatan, Vol. 01 No 02. 